дидактико-методичні особливості / П. М. Олійник // Методика навчання і наукових досліджень у вищій школі / С. У. Гончаренко, П. М. Олійник, В. К. Федорченко та ін. ; за ред. С. У. Гончаренка, П. М. Олійника. - К. : Вища шк., 2003. - С. 55-68.

УДК 514:371.3

Ірина Молдован

\title{
ДО ПИТАННЯ КЛАСИФІКАЦІЇ ГЕОМЕТРИЧНИХ УМІНЬ В УМОВАХ ЗАСТОСУВАННЯ МУЛЬТИМЕДІЙНИХ ЗАСОБІВ
}

Молдован I. В. До питання класифікації геометричних умінь в умовах застосування мультимедійних засобів навчання.

У статті з'ясовано питання класифікації геометричних умінь, зокрема потребу у iii конкретизації, в умовах застосування мультимедійних засобів навчання. Автор пропонує виокремлено уміння, пов'язані 3 роботою 3 мультимедійною дошкою, проекційною системою, у програмах пакету Microsoft Office та уміння, які формуються під час роботи із спеціальними навчальними програмами 3 геометрії. 3'ясовано, що мультимедійними засобами можна і доцільно формувати всі групи геометричних умінь. На прикладі фрагменту мультимедійної презентації показано можливості мультимедійного засобу у формуванні в учнів семіотичних умінь на уроці геометрії.

Ключові слова: класифікація умінь учнів, геометричні уміння, мультимедійні засоби навчання, мультимедійна презентація, навчання геометрії.

Молдован И. В. К вопросу о классификации геометрических умений в условиях применения мультимедийных средств обучения.

В статье раскрывается вопрос классификации геометрических умений, в частности выясняется потребность в ее конкретизации в условиях применения мультимедийных средств обучения. Автор предлагает выделять умения, связаные с работой с мультимедийной доской, проекционной системой, в программах пакета Microsoft Office и умения, которые формируются во время работы со специальными учебными программами по геометрии. Выяснено, что мультимедийными средствами можно и целесообразно формировать все группы геометрических умений. На примере фрагмента мультимедийной презентации показаны возможности мультимедийного средства в формировании у учащихся семиотических умений на уроке геометрии.

Ключевые слова: классификация умений учащихся, геометрические умения, мультимедийные средства обучения, мультимедийная презентация, обучение геометрии.

Moldovan I. V. The problem of the geometric skills classification in terms of the multimedia tools usage.

The article deals with the issue of geometric skills classification, in particular, it clarifies the necessity of its specification in the terms of multimedia tools usage. The author suggests to distinguish the skills related to the multimedia whiteboard functioning and the projection system in the programs of Microsoft Office and the skills, which are formed during the work with the special educational programs on geometry. It is cleared up that all groups of geometric skills can be formed with the help of the multimedia means. By the example of the fragment of the multimedia presentation the possibility of multimedia tools in formation of the pupils' semiotic skills at the geometry lesson are shown.

Key words: classification of pupils' skills, geometric skills, multimedia tools, 
multimedia presentation, teaching of geometry.

У Законі України Про Основні засади розвитку інформаційного суспільства в Україні на 2007-2015 роки відзначено, що одним з основних напрямків розвитку інформаційного суспільства в Україні- надання кожній людині можливості для здобуття знань, умінь i навичок 3 використанням інформаційно-комунікаційних технологій під час навчання, виховання та професійної підготовки [5]. Формувати ці уміння необхідно ще зі школи, зокрема під час навчання учнів геометрії. Геометрія як навчальний предмет у школі має широкі можливості для інтелектуального розвитку школярів і впливу на їхню особистість. Це зумовлено генетичними зв'язками геометричної науки 3 практикою, перетворювальною діяльністю i загальнокультурним розвитком людини. Навчання геометрії передбачає засвоєння учнями системи відповідних знань, формування умінь і практичних навичок, що сприяє розвитку їхнього логічного мислення, пам'яті, уваги, інтуїції, умінь аналізувати, класифікувати, узагальнювати тощо [2].

Проблему формування навчальних умінь у своїх дослідженнях з'ясували відомі психологи та педагоги (Ю. Бабанський, П. Гальперін, В. Давидов, Є. Ільїн, Л. Ітельсон, О. Леонтьєв, В. Онищук, О. Савченко, Н. Тализіна, І. Якиманська та ін.)

Формуванню математичних умінь присвячені праці Г. П. Бевза, О. Дубинчук, В. Кірмана, Ю. Колягіна, О. Скафи, 3. Слєпкань, М. Шкіля, С. Яценко та ін., зокрема геометричних умінь М. Бурди, О. Вашуленко, М. Волчастої, Н. Гібалової, Т. Гори, С. Іванової, М. Ігнатенка, Є. Неліна, Н. Салтановської, Н. Тарасенкової, Т. Тітової, М. Флімонової, О. Чашечникової, В. Швеця та ін.

В умовах модернізації системи освіти, яка має відповідати вимогам інформаційного суспільства, потребують осучаснення погляди на традиційні методи і технології навчання. Використання мультимедійних засобів у навчанні учнів математики досліджували Т. Архіпова, Д. Васильєва, С. Ганжела, Л. Грамбовська, М. Жалдак, М. Ковальчук, С. Семеріков, С. Раков, О. Скафа та ін.

Аналіз науково-методичної літератури, методичних комп'ютерних посібників, огляд низки презентацій свідчить, що нині недостатньо висвітлено питання використання мультимедійних засобів під час формування геометричних умінь учнів 8-9 класів основної школи.

Mema cmammi полягає в уточненні класифікації геометричних умінь учнів основної школи в умовах застосування мультимедійних засобів та виділенні можливостей мультимедійних засобів у їх формуванні.

Спираючись на власний досвід навчання учнів геометрії та проведене опитування вчителів математики, з'ясовано, що нині мультимедійна підтримка уроків $\epsilon$ необхідним складником навчання учнів геометрії, вона сприяє успішному формуванню геометричних умінь. Формувати їх необхідно як на уроках геометрії, так і під час самостійного опрацювання навчального матеріалу.

Під умінням будемо розуміти опановану дію учня (або більш складну діяльність iз вибором і застосуванням правильних прийомів роботи), яка складається з певної впорядкованої системи кроків, які поєднуються спільною метою [1; 3]. Під поняттям «геометричні уміння» будемо розуміти уміння, які опосередковано чи безпосередньо пов'язані з операціями над геометричними фігурами, із відношеннями між ними, їх взаємним розміщенням та побудовою, а також 3 геометричними величинами та ї відношеннями.

Сучасні науковці пропонують класифікації умінь, що характеризуються різним рівнем узагальненості та певними логічними обгрунтуваннями. До узагальненого 
підходу щодо класифікації умінь відносимо підходи: Ю. Бабанського (загальнонавчальні та спеціальні уміння), Н. Лошкарьової (спеціальні і загальні уміння), А. Усової (уміння практичного характеру та уміння пізнавального характеру) та ін.

Формуванню геометричних умінь учнів присвячені праці М. Бурди. Він виокремлює основи класифікації геометричних умінь за: 1) змістом геометричної діяльності (уміння - загальнопізнавальні, загальні, специфічні); 2) особливостями розумових дій (уміння - практичні, інтелектуальні, алгоритмічні, евристичні); 3) метою геометричної діяльності (уміння - створювати візуальні образи, графічні, розв'язувати задачі, оперувати твердженнями, обгрунтовувати твердження); 4) процесом засвоєння способів діяльності (уміння - орієнтовні, виконавчі, контрольно-коригувальні) [2].

Проаналізувавши низку праць $[1 ; 3 ; 4]$, поділяємо геометричні уміння на групи: $\begin{array}{llll}1) \text { загальнонавчальні; } & \text { 2) загальнопредметні; } & 3 \text { ) спеціальні }\end{array}$ Загальнонавчальні уміння зазвичай поділяють на чотири групи: навчальноорганізаційні, навчально-інформаційні, навчально-інтелектуальні та навчальнорефлексивні. На нашу думку, у групі загальнонавчальних умінь серед навчальноінформаційних більшу увагу необхідно приділяти умінням, які пов'язані 3 оперуванням інформацією під час роботи з технічними засобами (комп'ютером), програмним забезпеченням. До них пропонуємо відносити уміння: 1) працювати 3 програми з пакету Microsoft Office (MS Word, MS PowerPoint, MS Publisher, MS Excel тощо), а саме: набирати текстову інформацію в середовищі тощо; виконувати основні операції з текстовою інформацію в даних середовищах; додавати до документу таблиці, малюнки, діаграми тощо; 2) користуватися комп'ютерним джерелом інформації (знаходити необхідний матеріал, зберігати інформацію на локальні, жорсткі диски та флеш-пам'ять, відкривати, завантажувати ії на комп'ютер та ставити до друку); 3) працювати 3 гіперпосиланнями, відео, музикою, графікою в середовищі мультимедійних програм; 4) користуватися технічним засобами (мультимедійною дошкою, проекційною системою та ін.).

Як показує дослідження, під час вивчення шкільного курсу геометрії в учнів виникають труднощі, зокрема невміння перекодовувати геометричні факти у зрозумілу для них форму. Однією 3 причин труднощів $\epsilon$ низький рівень сформованості семіотичних умінь, які у свою чергу впливають на рівень сформованості предметних умінь. Тому у групі загальнопредметних виокремлюємо семіотичні, до яких відносять уміння [4]: 1) переходити від вербальної згорнутої до вербальної розгорнутої оболонки; 2) переходити від вербальної розгорнутої до вербальної згорнутої оболонки; 3) переходити від вербальної розгорнутої до вербальної розгорнутої оболонки; 4) переходити від вербальної згорнутої до вербальної згорнутої оболонки; 5) переходити від невербальної до вербальної розгорнутої оболонки; 6) переходити від невербальної до вербальної згорнутої оболонки; 7) переходити від вербальної згорнутої до невербальної оболонки; 8) переходити від вербальної розгорнутої до невербальної оболонки; 9) переходити від невербальної до невербальної оболонки (початкова і кінцева знаково-символічна оболонки є представниками одного виду невербальних знаково-символічних засобів); 10) переходити від невербальної до невербальної оболонки (початкова і кінцева знаково-символічна оболонки $є$ представниками різних видів невербальних знаковосимволічних засобів). Семіотичні уміння необхідно формувати на всіх етапах навчання учнів геометрії: актуалізація опорних знань, мотивація навчальної діяльності, вивчення нового матеріалу, застосування та закріплення нового матеріалу, 
узагальнення та систематизації, контролю і корекції знань, умінь, навичок.

Особливість геометрії як навчальної дисципліни полягає в тому, що для грунтовного засвоєння навчального матеріалу учні повинні уміти виконувати правильні геометричні побудови, а також уміти «зчитувати» відомості 3 готових рисунків. Осучаснення засобів навчання породжує потребу додатково виділяти уміння виконувати геометричні побудови у спеціальних навчальних програмах. Тому до цієї групи відносимо: 1) уміння виконувати елементарні геометричні побудови в середовищі MS Word, MS PowerPoint; 2) уміння виконувати геометричні побудови у спеціальних навчальних програмах таких, як Динамічна геометрія, GeoGebra, Gran 2D, Cinderella тощо.

Урахувавши цілі, завдання та зміст шкільного курсу геометрії в загальноосвітній школі, пропонуємо класифікацію геометричних умінь.

1. Загальнонавчальні вміння (стосуються всіх навчальних предметів). Їх можна поділити на дві підгрупи:

1) загальноорганізаційні вміння: а) навчально-організаційні (уміння визначати зміст, обсяг своєї навчальної діяльності, способи опрацювання навчального матеріалу; уміння самостійно планувати навчальну діяльність відповідно до загальних цілей та власних інтересів, прагнень, установок; здійснювати самоконтроль і самоаналіз навчальної діяльності; організовувати i здійснювати самоосвітню діяльність; організовувати і здійснювати діяльність у групі (уміння пояснювати, надавати допомогу, приймати допомогу тощо)); б) навчально-інформаційні (користуватися підручниками, посібниками, словниками, енциклопедіями, довідниками тощо; перевіряти одержану інформацію; складати класифікаційні схеми, таблиці; обирати зручну форму фіксації та подання інформації; працювати 3 програми 3 пакету Microsoft Office (MS Word, MS PowerPoint, MS Publisher, MS Excel тощо); користуватися комп'ютерним джерелом інформації та технічними засобами); в) навчально-інтелектуальні (охайно і швидко писати; виразно та усвідомлено читати; уважно сприймати інформацію; осмислювати навчальний матеріал (аналізувати, класифікувати, синтезувати, абстрагувати); встановлювати причинно-наслідкові зв'язки; застосовувати навчальний матеріал (з допомогою чи без); розв'язувати проблемні пізнавальні задачі тощо); г) навчально-рефлексивні (уміння оцінювати й осмислювати результати власних дій, здійснювати взаємоконтроль, самоконтроль, зокрема контролювати свої дій, контролювати логіку думок, бачити суперечності, аналізувати ситуацію, змінювати пояснення події залежно від умов, цілей тощо, тобто володіти різноманітними способами саморефлексії і самоконтролю);

2) загальнопізнавальні вміння (уміння аналізувати, узагальнювати, класифікувати, моделювати тощо).

2. Загальнопредметні уміння (характерні для математичних дисциплін) загальногеометричні уміння, які набувають особливої форми відповідно до специфіки змісту дисципліни та особливостей iї завдань: 1) уміння працювати 3 математичними текстами, таблицями, зображеннями; 2) уміння, пов'язані 3 прийомами розумової діяльності у сфері математичних об'єктів - прийомами роботи 3 окремими математичними поняттями й судженнями, доведеннями, прийомами, притаманними мисленнєвим операціям у галузі математики (аналізом, синтезом, конкретизацією, абстрагуванням тощо); 3) уміння зводити задачі до раніше розв'язаних, перекладати практичну ситуацію на мову геометрії, переформульовувати умову, уводити допоміжні елементи, будувати фігури, виконувати рисунок за умовою задачі тощо; 4) семіотичні уміння (уміння оперувати знаково-символічними засобами).

\section{3. Спеціальні предметні уміння (характерні для шкільного курсу геометрії)}


зазначені у переліку вимог до рівня загальноосвітньої підготовки учнів у процесі опанування змістом математичної компоненти освітньої галузі «Математика». До цієї групи відносимо й ті уміння, формування яких відбувається під час використання спеціальних навчальних програм для виконання геометричних зображень.

Як уже зазначалося, вагому роль у формуванні предметних умінь відіграє рівень сформованості семіотичних умінь. Тому детальніше зупинимось на можливостях використання мультимедійної презентації у їх формуванні під час повторення i систематизації навчального матеріалу з курсу геометрії 7 класу теми «Ознаки рівності трикутників». Ураховуючи рівень навчальних досягнень учнів, організовувалася робота 3 першою ознакою рівності трикутників може по-різному. За даними слайду (рис. 1) учні формулюють ознаку. Позиції 1-2 забезпечують перевірку сформованості уміння переходити від вербальної згорнутої оболонки до невербальної. Кнопка «Ознайомитися з формулюванням ознаки» $є$ активною, тому переходячи з позиції 2 до 4 відбувається перехід від невербальної оболонки до вербальної розгорнутої (рис. 1).

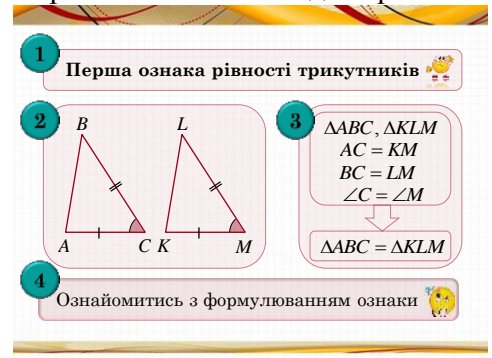

Рис. 1. Фрагмент мультимедійної презентації

Учитель може запропонувати учням самостійно сформулювати ознаку, потім виконати рисунок до неї (рис. 2).

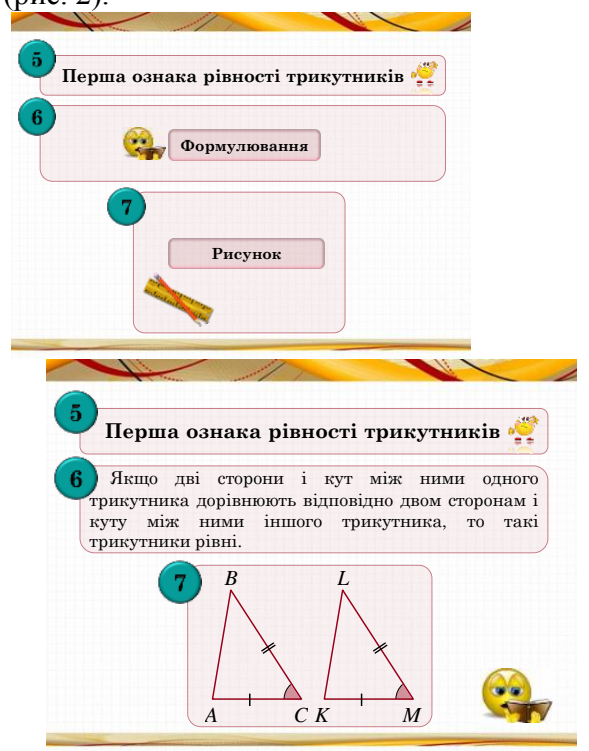

Рис. 2. Фрагменти мультимедійної презентації 
Правильність виконання цього ланцюжка перевіряється натисканням на відповідні активні кнопки. При цьому здійснюються переходи між вербальною згорнутою, вербальної розгорнутою та невербальною оболонками. Можливі переходи: 1) $5-6$;2) $5-7$; 3) 5-6-7.

На етапі пригадування ознак рівності прямокутних трикутників перевірити рівень сформованості семіотичних умінь можливо наступним чином (рис. 3 ).

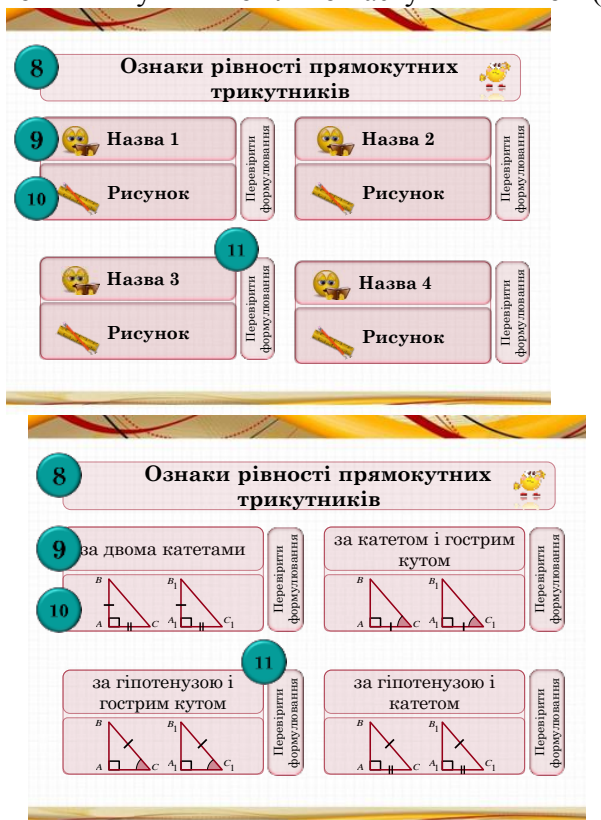

Рис. 3. Фрагменти мультимедійної презентації

Слайди містять навчальний матеріал, поданий у таких оболонках: вербальну згорнуту $(8,9)$, вербальну розгорнуту (11) та невербальну (10). Можливі ланцюжки переходів від однісї оболонки до іншої: 1) 8-9; 2) 8-10; 3) 8-11; 4) 8-9-10; 5) 8-10-11; 6) 8-9-11; 7) 8-9-10-11. Відповідно до рівня навчальних досягнень учнів, учитель самостійно обирає необхідний ланцюжок переходу. Після опитування учнів учитель має можливість продемонструвати учням правильні відповіді, натискаючи на кнопки 3 відповідними назвами. На нашу думку, для кращого запам'ятовування ці ознаки доцільно пригадувати саме на одному слайді.

Формувати семіотичні уміння доцільно й на етапі контролю знань. Учням можна запропонувати систему слайдів (рис. 4). 


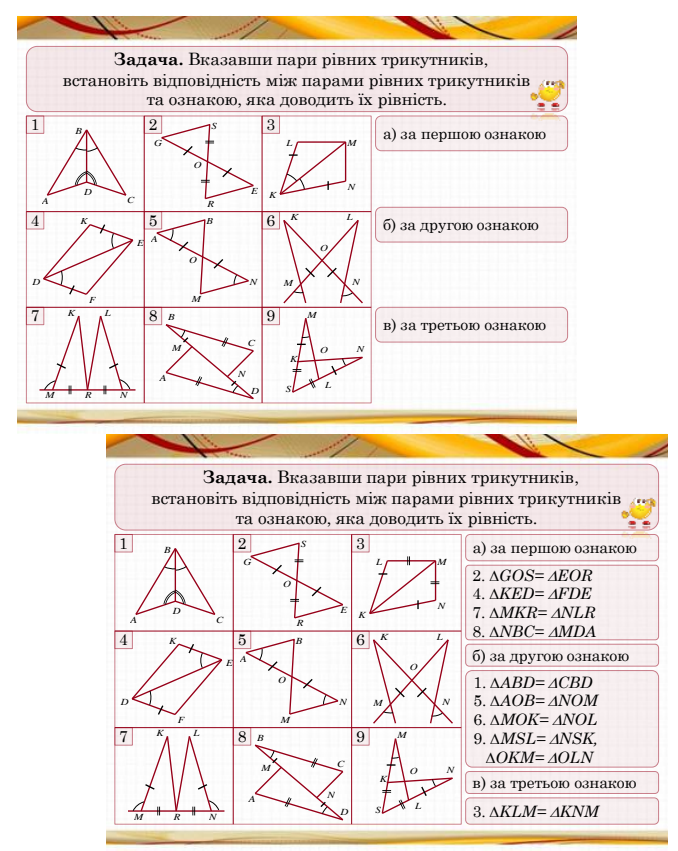

Рис. 4. Фрагменти мультимедійної презентації

Учням пропонується вказати пари рівних трикутників та ознаку, яка доводить їх рівність. Завдання може бути виконано учнями усно 3 покроковим поясненням, а також самостійно в зошитах 3 подальшою перевіркою. Окрім формування уміння застосовувати набуті знання у розв'язуванні задач, така система слайдів забезпечує формування уміння перекодовувати інформацію, переходити від невербальної оболонки до невербальної та до вербальної згорнутої тощо.

Нами деталізовано класифікацію геометричних умінь учнів основної школи. Процес формування в учнів умінь та їх якість залежить від багатьох факторів (індивідуально-психічних особливостей учня, змісту навчального матеріалу, педагогічної майстерності вчителя, навчальної матеріальної бази). За допомогою мультимедійних засобів навчання можна формувати як загальнонавчальні, загальнопредметні, так і спеціальні предметні уміння. Їх використання є доцільним у формуванні в учнів семіотичних умінь.

\section{Література}

1. Бурда М. І. Методичні основи диференційованого формування геометричних умінь учнів основної школи : дис. на здобуття наук. ступеня д-ра пед. наук : 13.00 .02 / Бурда Михайло Іванович. - К., 1994. - 347 с. 2. Вашуленко О. П. Методичні засади побудови системи вправ з геометрії в основній школі : автореф. дис. на здобуття наукового ступеня канд. пед. наук : 13.00 .02 / Ольга Петрівна Вашуленко; Нац. пед. ун-т ім. М. П. Драгоманова. - К. : Б. в., 2010. - 21 с. 3. Ильин Е. П. Проблема способностей: два подхода к ее решению / Е.П. Ильин // Психологический журнал. М., 1987. - Вып. 5. - С. 37-47. 4. Коломісць О. М. Диференційоване навчання аналітичної геометрії студентів вищих навчальних закладів педагогічного профілю : дис. на здобуття наук. ступеня канд. пед. наук: 13.00.02/ Оксана Миколаївна 
Коломієць. - Черкаси, 2009. - 298 с. 5. Про Основні засади розвитку інформаційного суспільства в Україні на 2007-2015 роки [Електронний ресурс]: закон України [затверджено Верховною Радою України від 9 січня 2007 року № 537-V]. - Режим доступу : http://zakon4.rada.gov.ua/laws/show/537-16.

УДК 37.091.2:221.895

Ольга Новак

\section{«АВТОРСЬКА ШКОЛА»: СУТНІСТЬ ПОНЯТТЯ, ОЗНАКИ, РІЗНОВИДИ ТА ОСОБЛИВОСТІ ДІЯЛЬНОСТІ}

Новак О. М. «Авторська школа»: сутність поняття, ознаки, різновиди та особливості діяльності.

У статті аналізується сучасний підхід до тлумачення поняття «авторська школа» у наукових розробках вітчизняних та зарубіжних учених, а також подано авторське тлумачення поняття «авторська школа». Визначено умови створення, характерні ознаки, різновиди та особливості функціонування авторського навчально-виховного закладу як інноваційної освітньої системи.

Ключові слова: навчально-виховний заклад, інноваційна школа, авторська школа, технологія, авторська технологія, педагогічна система, навчальний процес.

Новак О. М. «Авторская школа»: сущность понятия, признаки, разновидности и особенности деятельности.

В статье анализируется современный подход к толкованию понятия «авторская школа» в научных разработках отечественных и зарубежных ученых, а также подано авторское толкование понятия «авторская школа». Определены условия создания, характерные признаки, разновидности и особенности функционирования авторского учебно-воспитательного заведения как инновационной образовательной системы.

Ключевые слова: учебно-воспитательное заведение, инновационная школа, авторская школа, технология, авторская технология, педагогическая система, учебный процесс.

Novak O. M. «Authorial school»: essence of concept, sign, varieties and features of activity.

In the article the modern approach to interpretation of concept «authorial school» in scientific developments of Ukrainian and foreign scientists is analyzed. Authorial interpretation of concept «authorial school» is given. The terms of creation, characteristic signs, varieties and features of functioning of authorial educational-educator establishment as an innovative educational system are defined.

Key words: educational-educator establishment, innovative school, authorial school, technologies, authorial technology, pedagogical system, educational process.

Створення інноваційних навчально-виховних закладів освіти є пріоритетними напрямами державної політики України в галузі освіти, про що наголошується у Національній стратегії розвитку освіти в Україні на період до 2021 року. Тому, наявність нетрадиційних за типом освітніх закладів- ліцеїв, гімназій, коледжів, колегіумів, авторських шкіл - в освітньому просторі України є водночас: ознакою часу; відгуком на суспільний запит; результатом педагогічного пошуку освітян. Поява нових авторських шкіл, аналіз діяльності уже наявних навчальних закладів цього типу 